\title{
Application of GIS multi-criteria analysis and cartographic data presentation methods for public transportation optimization: the case of the town of Mińsk Mazowiecki
}

\begin{abstract}
The author attempts to apply a multi-criteria spatial analysis of issues related to urban public transport in terms of optimizing its usage and accessibility. Publicly available spatial and statistical data were used. Desktop GIS computer software was the primary tool and work environment - due to its popularity and wide interdisciplinary application in studying geospatial phenomena, processes, and dependencies. The article consists of two parts. The first identifies the research area, indicates the data used and the methodology of the conducted analysis, while the second presents the results of analyses in optimizing the functioning of public transport in Mińsk Mazowiecki (Mazowieckie Voivodeship, Poland) and recommendations that may contribute to disseminating the use of multi-criteria analyses in medium-sized cities.
\end{abstract}

Keywords: GIS, multi-criteria analysis, heat maps, public transport, optimization of transport accessibility

\section{Introduction}

The development of tools and environments for the description of geographical space has led to the dissemination of spatially oriented analyses. According to Chakhar and Mousseau (2015), multi-criteria analysis is a comprehensive analytical study of the interdependence of spatial data. Therefore, this type of analysis was indicated as a model solution in the discussed topic of optimization analyses in the GIS environment. The general accessibility and interdisciplinary of GIS make it applicable in practically every aspect of life, for example, in navigation, agriculture, real estate market analysis (Olszewski et al., 2007), ecology and environmental assessment (Hoffmann et al., 2018), road infrastructure safety management (Budzyński et al., 2018) or even the subject of this article which is transport accessibility analysis (Ford et al., 2015). The last-mentioned field is gaining more and more popularity as problematic urban areas are increasingly often considered from the point of view of space and the optimi- zation of its use. Transport accessibility is one of the significant factors determining the functional, social, cultural, and spatial development of cities striving for sustainable development (Korneć, 2018).

Accessibility maps, also known as time or transport accessibility maps, determine the ease of getting from site A to B (Pietrusiewicz, 1996). The first such map was developed in 1881, showing the time availability of London from anywhere in the world expressed in days of travel (Galton, 1881). Since then, the methods and the scale have been continuously refined. The contemporary issue of spatial accessibility focuses on collecting and processing spatial data to develop solutions to improve transport accessibility contributing to the sustainable development of cities (Burdziej, 2016). Moreover, good accessibility of public transport means may increase the value of the real estate by over $10 \%$ (Malasek, 2017), and the optimization of the location of public transport infrastructure may contribute to a significant increase in the number of its users (Ford et al., 2015). 
The analyses may represent data of different impact scales and complexity, for example, the travel time to a single educational institution (Bielecka \& Filipczak, 2010), the availability of many public facilities on a city scale (Burdziej, 2016), evaluation of time availability of the selected rescue service of a large city (Sitek et al., 2020) or an assessment of the availability of a sustainable transport system in a large agglomeration with a regional impact zone (Ford et al., 2015). Nonetheless of the scale, users should always be identified regarding their predisposition and spatial distribution (Burian et al., 2018). During obligatory trips and for a specific purpose, access to the public transport stop should include the largest possible number of potential users in its zone of influence while ensuring a high level of safety (Malasek, 2017). Moreover, it was proved that lack of adequate transport accessibility and too large spatial dispersion is resulting in a reduction of the range of service, which could be a key factor of depopulation and developmental delay as the people cannot fulfil their basic need for commuting (Turk et al., 2016). Therefore there is a significant need to analyse the factors determining the decision-making process of its choice as the means of transport and its accessibility.

\section{Analysis methodology and cartographic presentation of data}

According to Bielecka and Filipczak (2010), the methodology of transport accessibility analysis should be based on four essential stages - selection of the area within which accessibility will be determined, selection of the means of movement, data collection as well as distance and travel time calculations, and the last but not least assessment of the reliability and accuracy of the results along with the graphical presentation in the form of a thematic map (Bielecka \& Filipczak, 2010). A different approach to transport accessibility applies attraction-accessibility measures (Miller \& Wu, 2000). This method is based on the spatial collocation showing the dependencies influencing the transport attractiveness of selected areas with the required travel costs. Despite considerable achievements in developing transport accessibility, there are no specific and unified methodological principles for this type of study. Therefore, in the research process, both methods were adopted as the most appropriate to determine city residents' most optimal communication accessibility, whose way of moving is defined by the spatial distribution of individual facilities or areas of interest.

The subject of research of the article will be mainly achieved through the use of multi-criteria analysis. It was proved to be helpful in the decision-making process by examining the relationship between the advantages and disadvantages of various decision alternatives to achieve a specific goal (Adem Esmail et al., 2018). A properly conducted multi-criteria analysis must have clearly defined evaluation criteria which, according to Malczewski and Jaroszewicz (2018), must satisfy the measurability condition (the possibility of determining the value of the criterion), completeness (including all elements affecting the resulting decision), operability (data must have a meaningful and unambiguous analytical form), non-redundancy (avoiding re-use) and exhaustiveness (the number of criteria must be selected to describe the full substantive complexity of the issue). Furthermore, a criterion is itself a statement that represents both the idea and its attributes. Therefore, the use of this type of analysis is reliable in a GIS object-oriented environment, where each spatial object has assigned attributes.

The analytical tools based on the density and intensity of the phenomenon have been used, and the results of which were presented in the form of heat maps. The density of base data occurrence is presented in the form of a raster bitmap consisting of rectangular tiles (pixels), in which each tile is graded in a colour scale to demonstrate the value of the respective element (Wilkinson \& Friendly, 2009). Each pixel expresses the intensity of the occurrence of a specific attribute in the adjacent space, which is expressed in the form of so-called clusters that are an aggregation of a particular value (Rajaram \& Oono, 2010). As a result of such a process, heat maps are respectively representing geographic data density in the form of raster maps elaborated by applying kernel density estimation with a given radius (Słomska-Przech et al., 2021). As a result, it is possible not only to represent data graphically but also to determine the relationships of the spatial distribution of the phenomenon under study. It is doable to indicate areas of concentration or insatiable of the phenomenon (Pokojski et al., 2021). 
The dissemination of spatial databases and GIS systems has made heat maps significantly popular to present data in the form of continuous and smooth maps that are intuitive to read (Słomska-Przech et al., 2021) and capable of presenting every type of data (Pettit et al., 2012). They could be used for data visualization in infection control epidemiology describing the relationship between hospital-acquired infections (Ohannessian et al., 2017), understanding the social aspects of communities networking (Gove et al., 2011), in fire risk analysis (Liu et al., 2019), visualisation of efficiency coverage and energy consumption (Jeong et al., 2011) or in the visualization of popular jogging routes collected from tracking data based clients (Sainio et al., 2015). The commonness of the GIS environment and the development of web mapping systems will contribute to the further wider use of heat maps due to their simplicity and the effectiveness of the information implication (DeBoer, 2015).

\section{Data and limitations}

As the primary source of data, the Database of Topographic Objects in the scale 1:10,000 (BDOT10k) (Główny Urząd Geodezji i Kartografii, n.d.) was used, containing spatial objects in vector form, such as, for example, roads, buildings divided into functions, industrial areas, communication stops, and others. Statistic data of Statistics Poland (Główny Urząd Statystyczny, hereinafter as GUS), concerning mainly demographics, were also used to present the whole aspect of the spatial oriented analysis (Polska w liczbach, n.d.).

It should be borne in mind that the analysis results may be burdened with an analytical error because due to the outbreak of the COVID-19 pandemic and the introduction of a nationwide lockdown, aspects of everyday functioning, including private and professional life, changed. Research related to socio-cultural aspects showed that the SARS-CoV-2 pandemic reduced the need for movement due to the introduced restrictions and the dissemination of home office work, remote learning, or even online services (Roberts, 2020). In a post-pandemic reality, this could lead to a complete reorganization of workplaces (Wang et al., 2021), but the movement need will never be entirely eliminated. However, the growing number of vaccinations and in- creasing public awareness in the last few months have led society and the economy to function thereabout similar to pre-pandemic. Every aspect of life will eventually return to normal. Therefore, a second up-to-date analysis should be carried out to verify the results along with the new behavioural stimuli study. These results could help operators implement strategies to adapt their service to reunite and retain public transport users (Awad-Núñez et al., 2021). Nevertheless, the results of the carried out study presented in this article focus on spatial aspects rather than the social aspects of everyday life functioning, which could help achieve the aim stated above.

\section{Multicriteria analysis methodology}

The methodology of optimization analysis is based on the analysis of spatial statistics allocations, in which the relationships between vector objects with information layers located in space are examined (Suchecka, 2014). The analyses were carried out with the Model Builder tool in the ArcGIS software, in which a block diagram was built (fig. 1). The use of Python language enabled the automation of the result and decision-making process. Each criterion of the so-called traffic generators was also developed in the GIS environment and then presented in the form of the clustered spatial distribution of a given criterion phenomenon heat maps - individual and summarised criteria heat maps. The last essential step of analysis is the transition from the polygon to the point form. It will allow the use of the GIS Network Analysis tool, which will indicate potential locations with as many analysis criteria as possible within the desired distance (Jensen \& Jensen, 2013; Cichociński \& Dębińska, 2012), in this case, 400 meters which stand for the most convenient and acceptable walking distance to the bus stop (Kim et al., 2005). It will be achieved by designating the most optimal pedestrian access along linear roads and paths layers. Additionally, to avoid marking points in the inaccessible areas or too far from the driveline, 3.5 meters wide buffer zones from the road edge were established, in which points are only possible to be located corresponding to the average width of the non-driving road part in the city (pavement, parking spaces, etc.). 


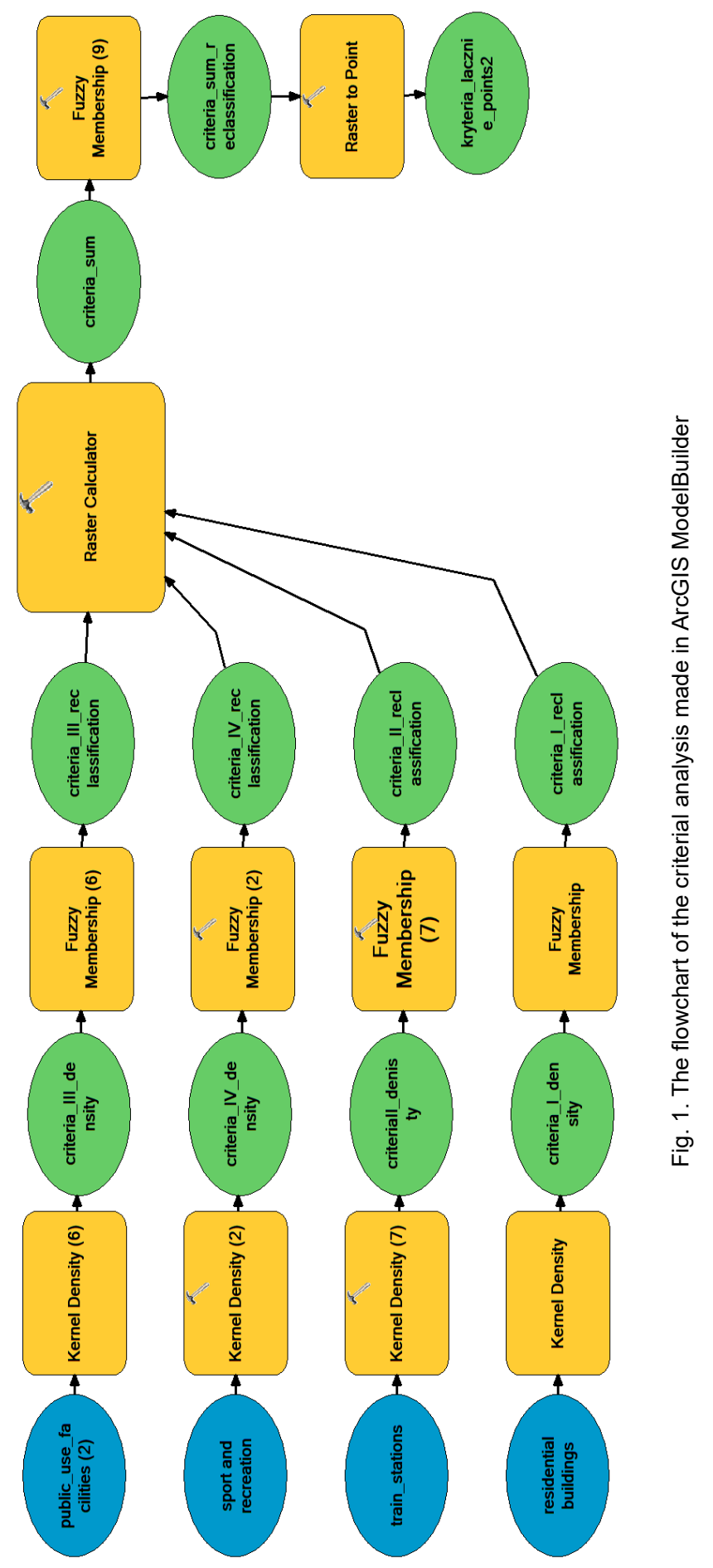




\section{Criterion I- population clusters}

In the author's opinion, the first and most important criterion was population congestion, as the passenger starts the journey from the vicinity of his place of residence and then returns to it. Due to the lack of up-to-date and area-oriented data, an algorithm was elaborated to allow for an approximate determination of the number of residents living in single-family and multi-family buildings obtained from BDOT10k. In the first case, only the GUS index for Mińsk Mazowiecki was used, referring to the average number of people per one household, amounting to 2.34 people.

Number of residents $=$ $=$ building $* 2.34=14,792$ people

For multi-family housing, the indicator of the average usable floor space of a flat per 1 person
In total, the estimated number of residents was 40,676 people, which - compared to the actual

Number of residents $=$

$$
\begin{gathered}
=\frac{((\text { building area } * \text { number of floors }) * 0.75)}{27.40 \mathrm{~m}^{2}} * 2.34= \\
=25,884 \text { people }
\end{gathered}
$$

population of 40,999 (as of 2019), is the desired result within the limits of the miscalculation.

The spatial distribution of the areas with the most significant potential for public transport is concentrated in the central part of the city (fig. 2). These areas are filled with compacted multi-family housing. The further to the west and north of the central zone, the intensity of buildings decreases. It is related to the spatial development of residential suburbs dominated by

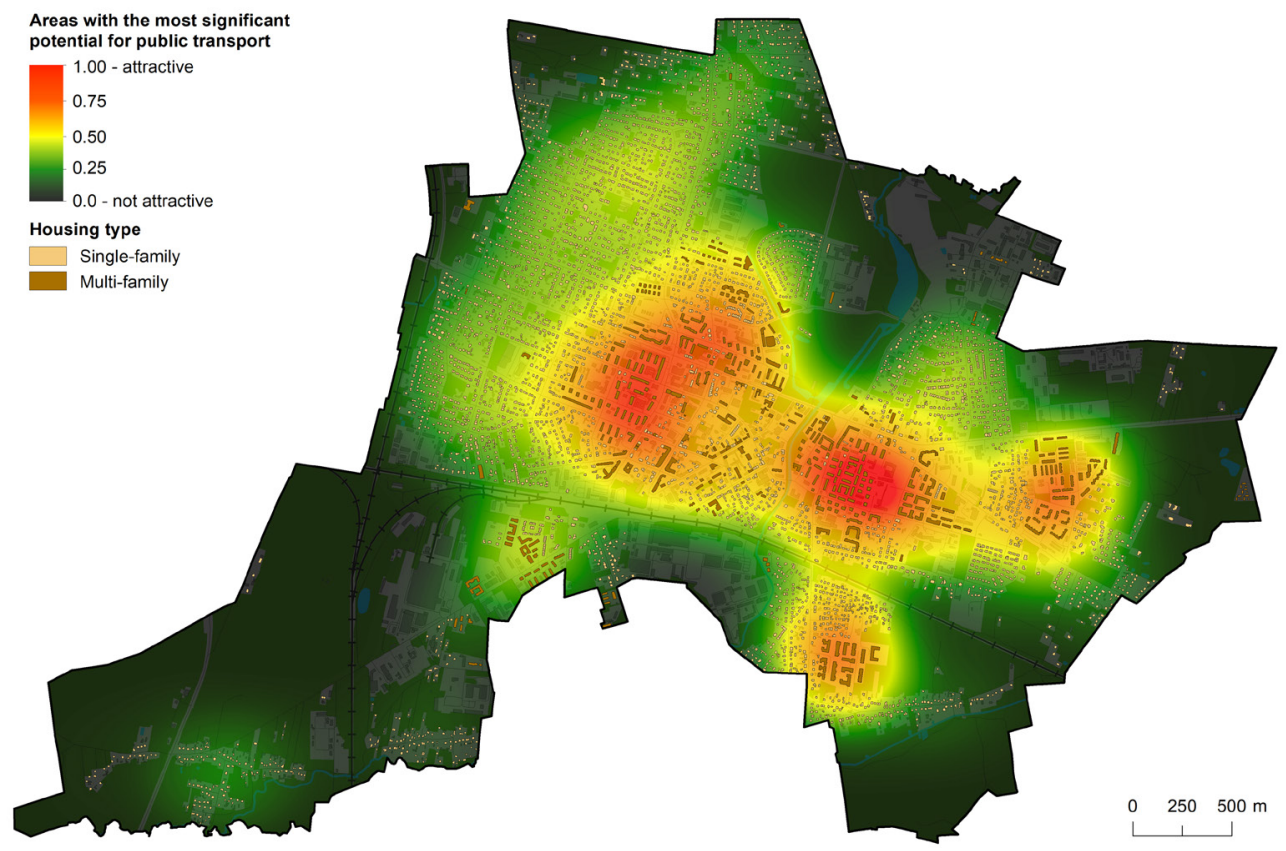

Fig. 2. Areas with the most significant potential for public transport in means of housing

was $27.40 \mathrm{~m}^{2}$, the indicator of the average number of people per 1 family house, and the approximate indicator describing the usable floor area of the building, amounting to 0.75 of the building area. extensive single-family housing. On the other hand, the southern clusters are characterized by relatively high clusters dispersed spatially due to the industrialization of the southern city part and non-urbanized investment areas. 


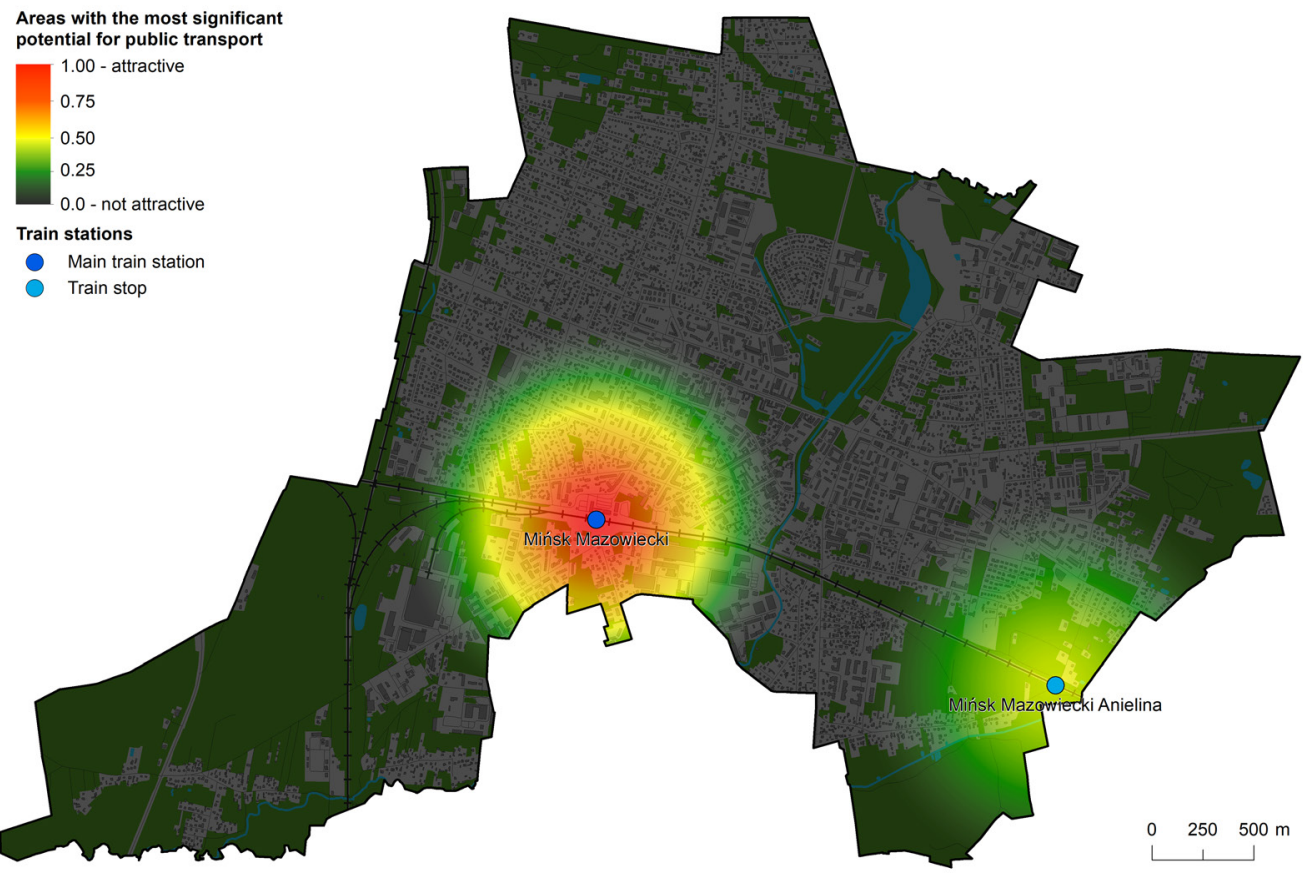

Fig. 3. Areas with the most significant potential for public transport in means of train transit

Areas with the most significant potential for public transport

1.00 - attractive
0.75
0.50
0.25
0.0 - not attractive Public use facilities

D Culture institution

D Education institution

Healthcare

血 Public administration

團 Major shopping facility

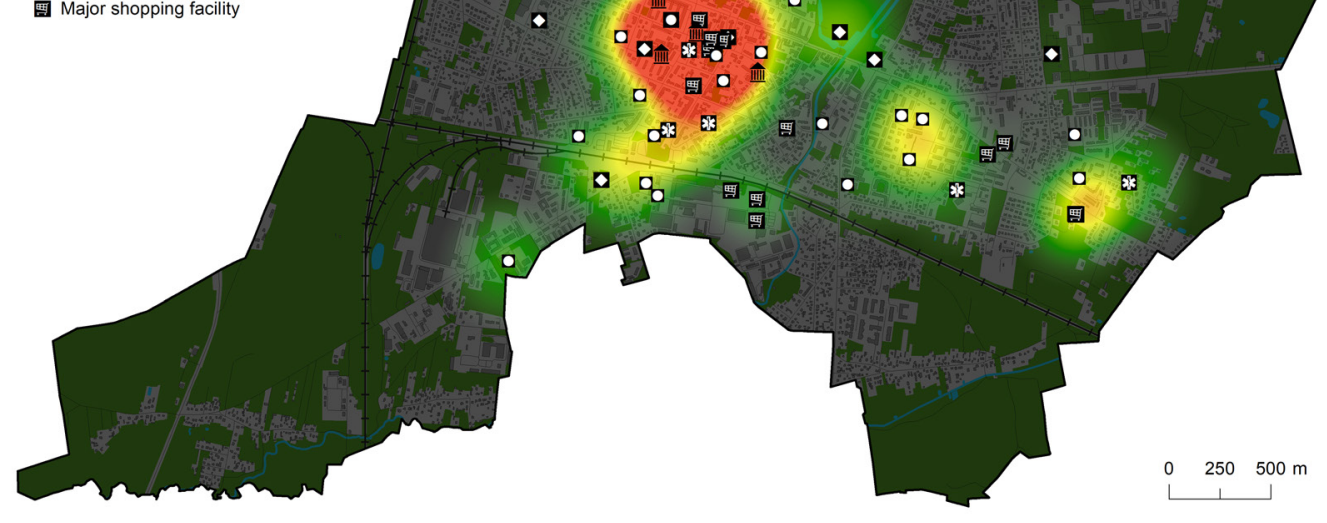

Fig. 4. Areas with the most significant potential for public transport in means of public use facilities 


\section{Criterion II - rail transit}

The second criterion focuses on rail transit passenger flow. The indicated analysis criterion is a key (albeit external) factor determining the city's dynamic development due to direct and fast rail connections with the Warsaw agglomeration. The urban sprawl of large cities leads to the growth of suburban zones serving the purpose of city bedrooms (Harasimowicz, 2018). In this criterion analysis, the statistical data of the GUS on the daily passenger rotation in 2016 were used to create a heat map (fig. 3). Both railway stations were taken into consideration as one of the major traffic generators. The data regarding the railway passenger rotation at the stations mentioned above was adopted as the value determining the analytical intensity in the range of 800 meters train station service (Kim et al., 2005). Daily transit ratio proved that city is transit-oriented, as proof of which its main station was the second busiest train station in Mazowieckie Voivodeship outside the capital city. Both stations served about 8,600-9,100 passengers daily, of which the main station handled 7,600 passengers (as of 2015).

\section{Criterion III - public use facilities}

The third criterion analysis (fig. 4) confirmed that Mińsk Mazowiecki is suffering the problem typical for medium-sized cities - centralization of socio-cultural services (Majewska, 2021). The central zone of Mińsk Mazowiecki has a high density of all types of institutions, such as schools, healthcare, administration, major shopping facilities, and cultural institutions. This type of spatial distribution results in an excessive and cumulative need to commute towards the city centre, leading to significant communication difficulties and the underinvestment of the suburbs. Nevertheless, three crucial functional and spatial clusters were identified outside the downtown. Two to the east are related to education, with the largest municipal schools attended by 3,660 students, which corresponds to $54.5 \%$ of the capacity of all the schools in the city (top left 2,511 students $(33.1 \%)$, left 1,629 students $(21.4 \%)$; Polska w liczbach, n.d.). The last relevant area was identified in the far eastern urbanized part of the city, and it has a cumulative basis for various public facilities serving one of the most extensive multi-family housing estate.

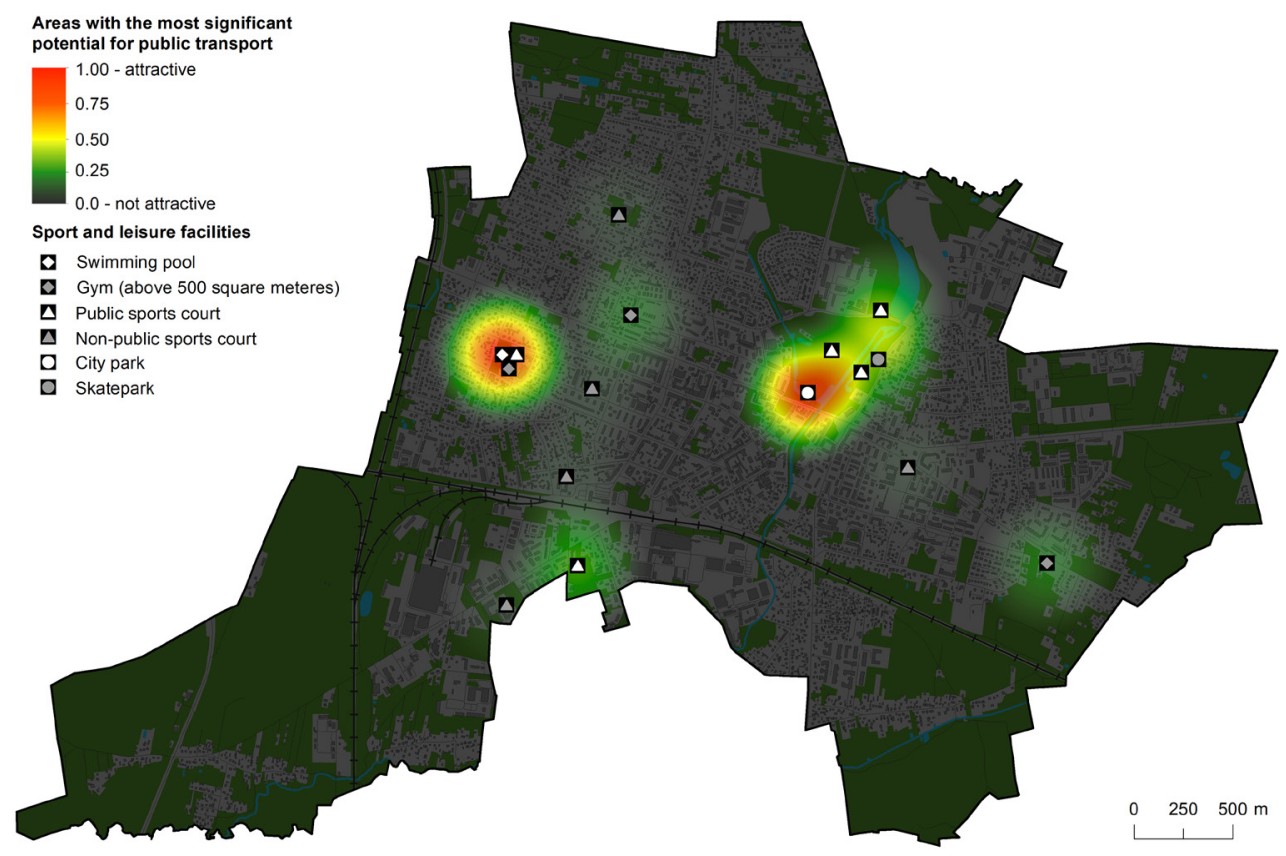

Fig. 5. With the most significant potential for public transport in means of sport or leisure facilities 


\section{Criterion IV - sports and leisure facilities}

The last but not least criterion that was taken into account in the analysis of transport accessibility is the density of sports and recreational facilities (fig. 5). The spatial distribution of the clusters of the examined criterion divides the city into two parts - eastern and western. In the first case, the main concentration is the city park with an open to public sports complex nearby to the north. These green public spaces are the only significant area of urban greenery offering various leisure and recreation opportunities. There is a large playground, an outdoor gym, a skate park, sports fields and courts, and even a water equipment rental. On the other hand, the western aggregation has a significant concentration of sports facilities as part of the municipal sports and recreation centre - a gym, aquapark, multi-functional sports fields, and a seasonal ice rink.

\section{Criteria weighting model}

Referring to the diverse needs and perception of public transport as a means of transport (Burian et al., 2018), a social study was conducted. To reduce the risk of biased analysis a system of weighting criteria, independent of the author, was developed following the online survey results on the role, importance, and perception of public transport. The number of survey participants was 726 people, and they were asked a series of questions to identify the willingness and means of transport they are using to meet their basic needs. The survey was conducted online using the question form, which was made available on social media, on the website of the City Hall of Mińsk Mazowiecki, and in the local seniors club. The broad spectrum of possible access to the questionnaire made it possible to attract respondents from every social and age group living in towns of various sizes. The most numerous group are people aged 18-26 (36.8\%) and 27-40 (27.6\%), while the $41-65$ age group counts for $17.3 \%$ of the total participants. The least influential groups are people under $18(11.1 \%)$ and those over $65(7.2 \%)$. The respondents mainly come from medium-sized cities with 20,000-100,000 inhabitants $(46.8 \%)$ and large cities with more than 100,000 inhabitants $(34.8 \%)$. The natives of small towns with up to 20,000 inhabitants and villages account for $10.0 \%$ and $8.4 \%$, respectively.

As part of the survey, participants were asked about their place of residence - a single-family or multi-family building. The results indicated that residents of multi-family housing are more frequent users of public transport than residents of single-family houses. In the first case, when asked "How often do you usually use public transport?" (fig. 6), the answer every day or a few times a week was indicated by $82.2 \%$ of people living in multi-family housing and $62.1 \%$ of single-family housing. In turn, to the question "How often do you usually use the car?" $26.8 \%$ of the people living in single-family

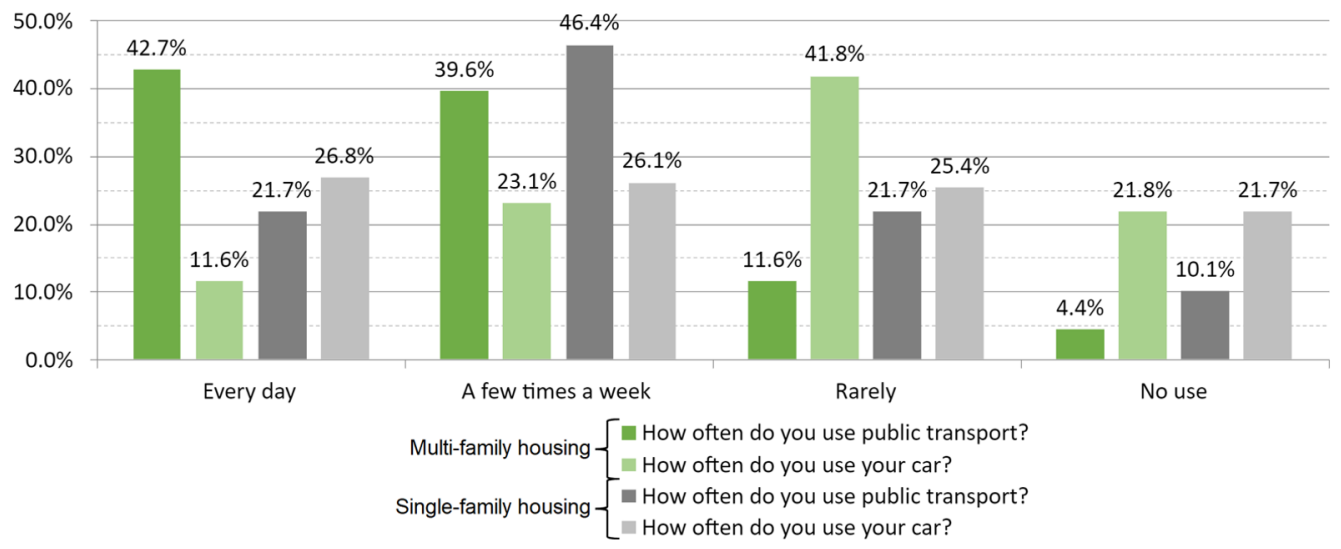

Fig. 6. Survey results chart of responses to the question How often do you use public transport or car 


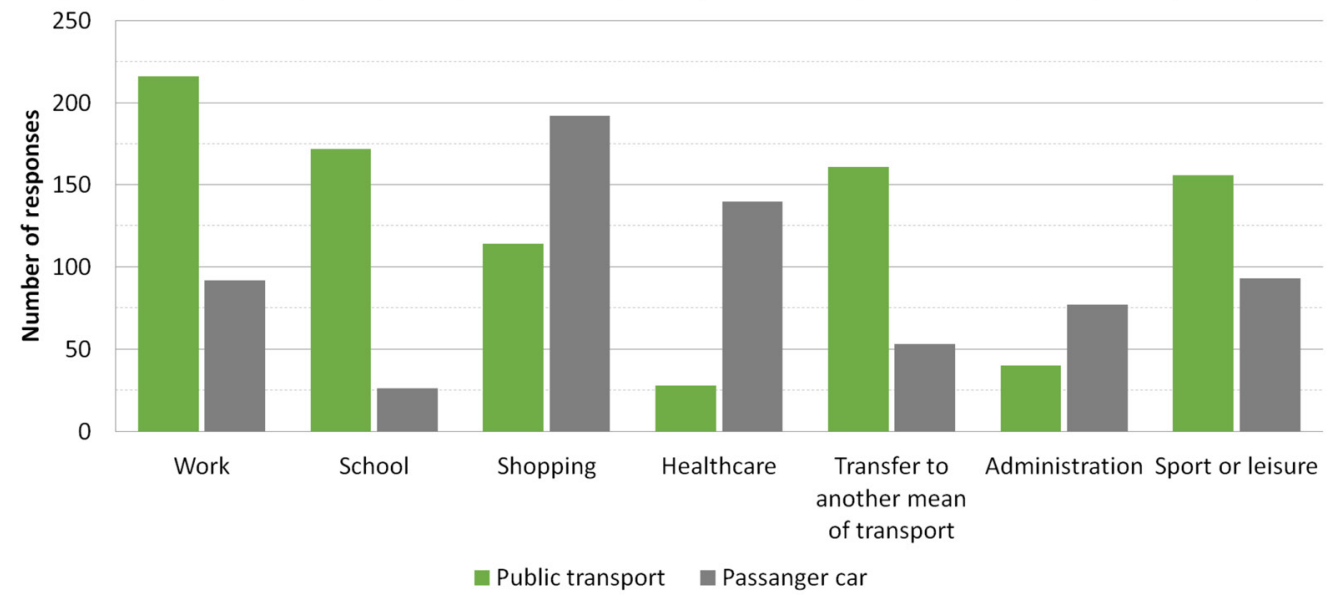

Fig. 7. Survey results chart of responses to the question What is your main purpose of travel by public transport, and which by car

houses declared that they use a car every day, and $26.1 \%$ a few times a week. In terms of the respondents living in multi-family housing, amount of answers stand for accordingly $11.5 \%$ and $23.1 \%$. The results mentioned above lead to the general conclusion that statistically more frequent public transport users are the residents of multi-family housing rather than single-family houses. The willingness to use public transport decreases with the increasing extensiveness of single-family residential buildings due to longer journey times and more alternative possibilities of individual and comfortable commuting, mainly by private cars (Burian et al., 2018).

The further part of the public opinion poll showed that public transport has a significant lead over individual traffic in commuting (216 responses), school (172 responses), satisfying the need for entertainment and leisure (156 responses), and switching to another means of transport (161 responses). These answers create a relationship between the destination and the preferred means of transport, indicating that public transport is the most common means of transport in regular activities such as work, study, or rest (fig. 7).

The categories with the superiority of using individual means of transport are travels to shopping facilities, healthcare or administration facilities. In the first case, 192 people indicated that they use individual transport to do the shopping. Subsequently, the vaster part of the respondents stated that they use private cars to fulfil consultations or medical assistance needs. However, the result of conducting official matters in the administration facilities is ambiguously explainable. Probably the respondents were motivated by the fact that when performing the indicated activity in administration facilities, it is not possible to determine the time needed to accomplish a given need - sometimes it takes a few minutes, and sometimes it takes a long while. This explanation may also apply to all stated activities as the private car is not limited by the arrival and departure time and is also the most comfortable means of transport.

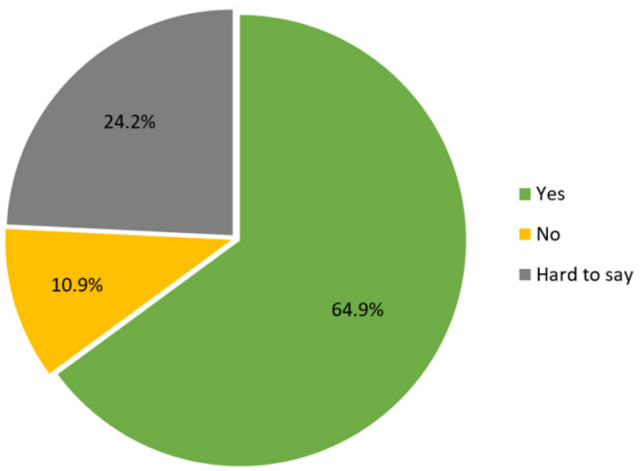

Fig. 8. Survey results chart of responses to the question Do you intend to use public transport more often when the pandemic situation stabilizes 
Within the survey considerations, one additional question was carried out, in which people were asked whether, after the pandemic situation stabilises, the respondents intend to use public transport more often. $64.9 \%$ of the respondents agreed that they intend to do so, $24.2 \%$ were unsure, and $10.9 \%$ did not anticipate such an increase (fig. 8).

The data obtained from the survey were subjected to min-max normalization using a linear function that brings the data to the desired range of values, where it was assumed that the maximum weight value is 0.3 and the minimum weight set to 0.05 (tab.1).

\section{Results of multi-criteria analysis}

Summing up all the criteria values made it possible to obtain the entire distribution of city-wide traffic generators, which had the most significant impact on the functioning and use of public transport (fig. 9). Predictably, with the accumulation of many clusters of individual criteria, the city centre proved to be the area with tremendous potential for transport services
Tab. 1. Criteria weights of analysis

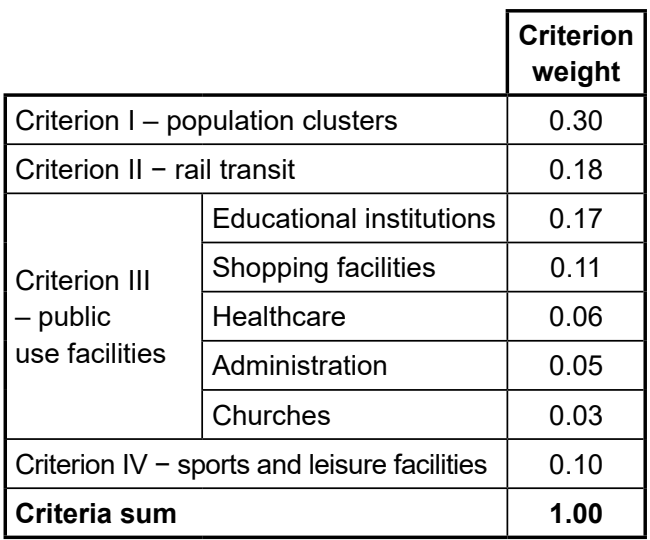

accommodating all the considered traffic generators. In addition, the city centre is surrounded by intense population congestion indicating that this area is very beneficial for city transportation.

Other areas of the city resulting in high transport attractiveness are the eastern and southern zones of the city. In the first case,

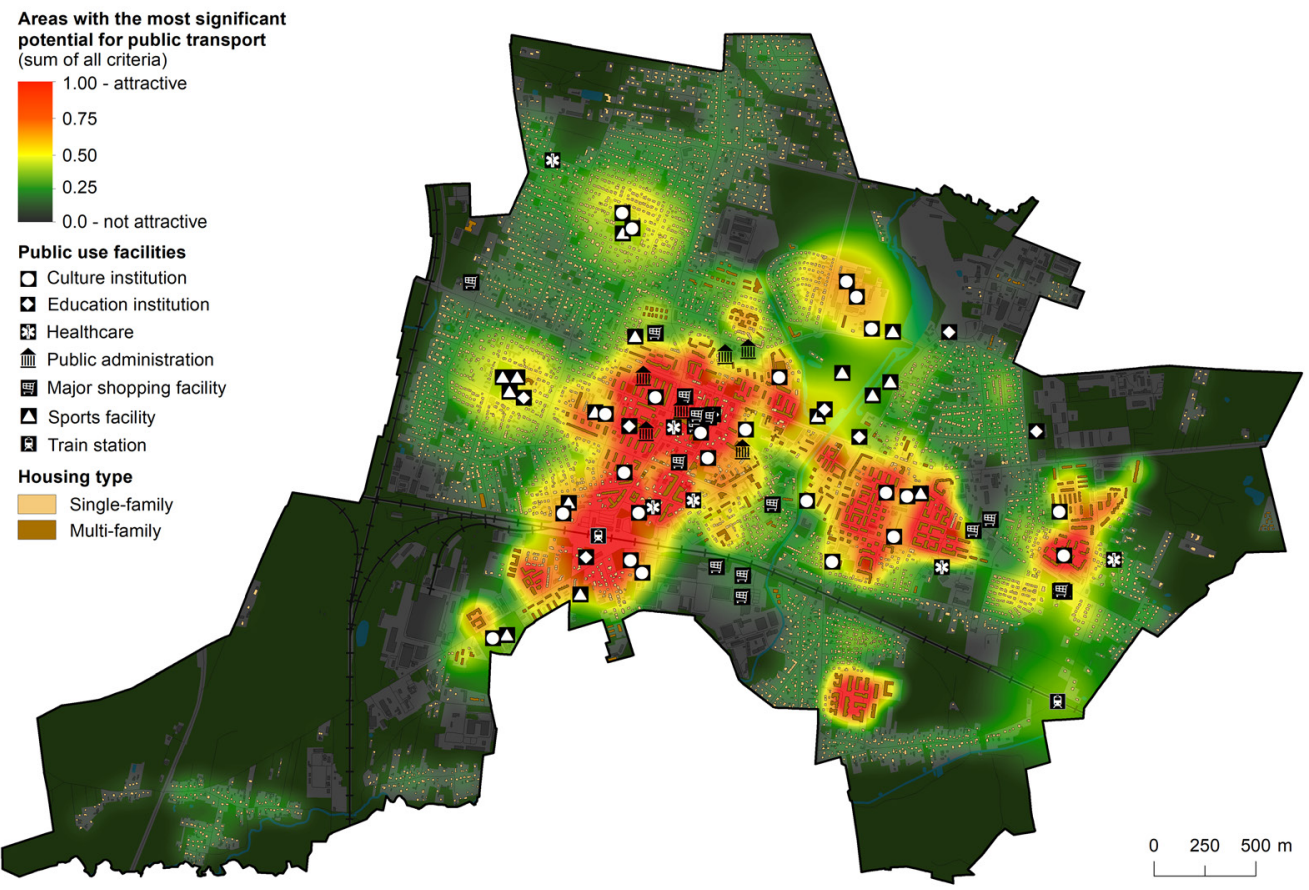

Fig. 9. Areas with the most significant potential for public transport (sum of all criteria) 
strongly dense historical multi-family housing, modern or the eastern large-panel housing estates dominate. The cited areas have numerous traffic generators in the kind of education, healthcare, sports, and recreation facilities. Nevertheless, concerning the significant spatial span of the indicated areas, the missing institutions are shopping, culture, and religious centres. As a result, eastern densely populated districts require regular transportation services toward the west direction.

The remaining areas of the city are less attractive in terms of generated traffic. The only areas that stand out from the rest are the clusters near northern education institutions and western recreational and religious facilities. It must be noted that the northern and western parts of the city have little potential due to the extensive housing development and the deficiency of services attracting traffic (Burian et al., 2018). In connection with the above, it is expected that potential bus lines running to the west and north may be exposed to low usage. Nevertheless, the so-called vicious circle of congestion must be prevented, as it leads to residential areas remaining outside the public transport service with a simultaneous increase in individual traffic. This uncalled-for situation can increase infrastructure maintenance costs, environmental degradation, and poor quality of life (Korneć, 2018). A similar statement applies to the South-West and South-East urban areas, which require special attention to avoid transport exclusion due to their peripheral location. Moreover, the indicated regions are the principal reserves of the city's further development areas. Therefore consolidating the strong position of public transport may contribute to their faster development and increase investment attractiveness in the city.

Moving on to the last analysis step, 80 most attractive locations were selected as a result of the GIS Network Analysis tool. After verification, thirty-four locations were proposed for new stops with high transport accessibility potential. Twenty-six proposals were rejected due to the physical impossibility of building or expanding the infrastructure as well as another twenty,

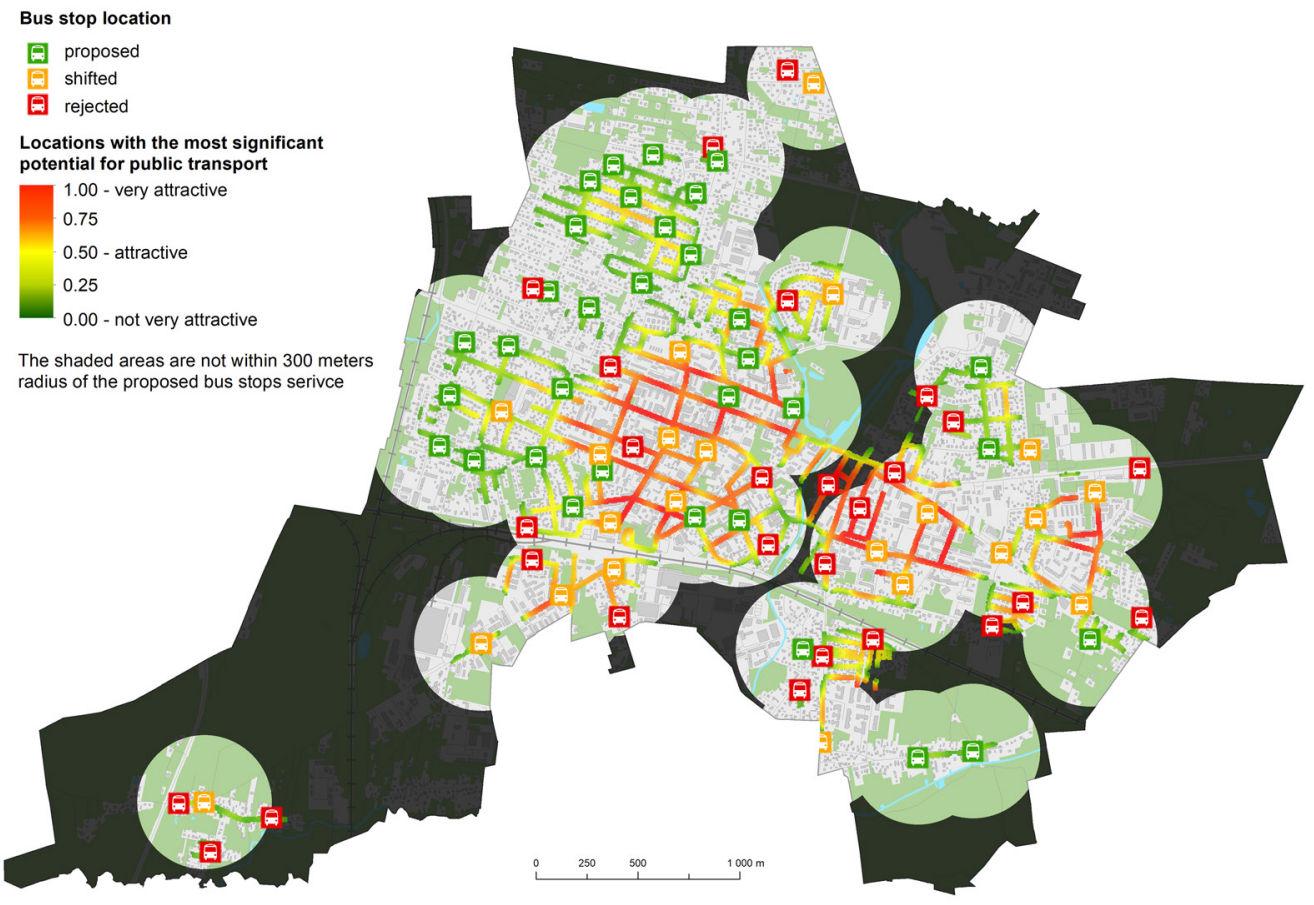

Fig. 10. Locations with the most significant potential for public transport with results of the stop location proposal 
were moved to use existing nearby infrastructure (fig. 10). With proposed locations, $83 \%$ of all urbanised city areas were within 400 meters of the most convenient walk to the bus stop (Kim et al., 2005). Moreover, $92 \%$ of all residential areas were within the desired distance of the public transport service range. Further work related to the design of bus lines using the demonstrated potential should be carried out based on three principles of attractive public transport - time, directness, and cost of travel (Lunke, 2020; Hrelja et al., 2016). This solution will most likely maximise undertaken analysis potential resulting in public transport accessibility and usage increase.

\section{Conclusions}

In conclusion, carrying out multi-criteria analyses is a process that requires an appropriate workflow adapted to local needs. The methodological solutions proposed in the article may be an extraordinary opportunity to promote the spatial analysis of data, especially in smaller urban units. Owing to this, it is possible to rationalise expenses by optimizing the functional and spatial aspects of the city. Presented optimization models in addition to the common availability of GIS environment tools, the above-mentioned proprietary solutions could be a superior opportunity to promote comprehensive analyses of spatial data, as well as to use intuitive cartographic presentation methods. The cartographic presentation in the form of a heat

\section{Literature}

Adem Esmail, B., Geneletti, D., \& Dicks, L., (2018). Multi-criteria decision analysis for nature conservation: A review of 20 years of applications. Methods in ecology and evolution, 9(1), 42-53. https:// doi.org/10.1111/2041-210X.12899

Awad-Núñez, S., Julio, R., Gomez, J., Moya-Gómez, B., \& González, J. (2021). Post-COVID-19 travel behaviour patterns: Impact on the willingness to pay of users of public transport and shared mobility services in Spain. European Transport Research Review, 13(1), 1-18. https://doi.org/10.1186/ s12544-021-00476-4

Bielecka E., Filipczak A. (2010). Zasady opracowywania map dostępności. Roczniki Geomatyki, 8(6), 29-38. map is a graphical representation of the density of geographic data as a result of the vicinity analysis of examined criteria. This method may be applied not only in optimizing city transportation functioning but also in other analyses examining the spatial distribution of particular spatial objects and phenomena. In addition, the advantage of using heat maps is their intuitiveness of the message for people who do not have substantive analytical knowledge in the field of a given analysis.

Mińsk Mazowiecki was presented as a model example of the use of transport accessibility analysis. However, while interfering with the current transport system of a city with a population of nearly 41,000 , attention should be paid to the interests of the inhabitants as not every resident is a driver and not every driver is a potential passenger of public transport. Some travellers are guided by determinative aspects, such as travel time and cost, while others are guided by factors that are not reliable, for example, concern for the environment, safety, or comfort. It does not change the fact that in the case of the entirety of urban transport, tremendous potential in the long-term perspective is public transport, which can quickly, directly, and cheaply transport large streams of people. For this reason, the local authority, as the institution closest to the resident, should consider implementing changes using the presented optimization proposal model to improve the public transport accessibility of residents.

Budzyński, M., Kustra, W., Okraszewska, R., Jamroz, K., \& Pyrchla, J. (2018). The use of GIS tools for road infrastructure safety management. E3S Web of Conferences. Seminary on Geomatics, Civil and Environmental Engineering (2017 BGC), 26, 00009. https://doi.org/10.1051/e3sconf/20182600009 Burdziej, J. (2016). Analiza dostępności przestrzennej za pomocą technologii GIS na przykładzie obiektów użyteczności publicznej w Toruniu. Prace Komisji Geografii Komunikacji PTG, 19(1), 43-51. https://doi.org/10.4467/2543859XPKG.16.004.6302

Burian, J., Zajíčková, L., Ivan, I., \& Macků, K. (2018). Attitudes and motivation to use public or individual transport: A case study of two middle-sized cities. Social Sciences, 7(6), 83. https://doi.org/10.3390/ socsci7060083 
Chakhar, S., \& Mousseau, V. (2017). Multicriteria Decision-Making, Spatial. In S. Shekhar, H. Xiong \& X. Zhou (Eds.), Encyclopedia of GIS (2017 Edition, pp: 1396-1404). Springer International Publishing.

Cichociński P., \& Dębińska E. (2012). Badanie dostępności komunikacyjnej wybranej lokalizacji z wykorzystaniem funkcji analiz sieciowych. Roczniki Geomatyki, 10(4), 41-48.

DeBoer, M. (2015). Understanding the heat map. Cartographic Perspectives, (80), 39-43. https://doi. org/10.14714/CP80.1314

Ford, A., Barr, S., Dawson, R., \& James, P. (2015). Transport accessibility analysis using GIS: Assessing sustainable transport in London. ISPRS International Journal of Geo-Information, 4(1), 124-149. https://doi.org/10.3390/ijgi4010124

Galton, F. (1881). On the Construction of Isochronic Passage-Charts. Proceedings of the Royal Geographical Society and Monthly Record of Geography, 3(11), 657-658.

Główny Urząd Geodezji i Kartografii, (n.d.), Zintegrowane kopie baz danych obiektów topograficznych BDOT10k. Retrieved 24 August 2020, from http:// www.gugik.gov.pl/pzgik/zamow-dane/baza-danych-obiektow-topograficznych-bdot-10k

Gove, R., Gramsky, N., Kirby, R., Sefer, E., Sopan, A., Dunne, C., Shneiderman, B., \& Taieb-Maimon, M. (2011). NetVisia: Heat Map \& Matrix Visualization of Dynamic Social Network Statistics \& Content. Proceedings of the 2011 IEEE Third Int'l Conference on Privacy, Security, Risk and Trust and 2011 IEEE Third Int'l Conference on Social Computing (pp. 19-26). IEEE. https://doi.org/10.1109/passat/ SocialCom.2011.216

Harasimowicz, A., (2018). Suburbanizacja a rola obszarów otaczających miasto - ujęcie teoretyczne. Studia miejskie, (29), 115-130. https://doi.org/ 10.25167/sm2018.029.08

Hoffmann, P., Lisiak, M., \& Borowiak, K. (2018). Zastosowanie narzędzi GIS w edukacji z zakresu gospodarki przestrzennej i ochrony środowiska. Acta Universitatis Lodziensis. Folia Geographica Socio-Oeconomica, (34), 45-60. https://doi.org/ 10.18778/1508-1117.34.03

Hrelja, R., Pettersson, F., \& Westerdahl, S. (2016). The Qualities Needed for a Successful Collaboration: A Contribution to the Conceptual Understanding of Collaboration for Efficient Public Transport. Sustainability, 8(6), 542. https://doi.org/10.3390/su8060542

Jensen, J. \& Jensen, R. (2013). Introductory Geographic Information Systems: International Edition. Pearson.

Jeong, Y., Chung, Y., \& Park, J. (2011). Visualisation of efficiency coverage and energy consumption of sensors in wireless sensor networks using heat map. IET Communications, 5(8), 1129-1137. https:// doi.org/10.1049/iet-com.2010.0723
Kim, J., Kim, J., Jun, M., \& Kho, S. (2005). Determination of a bus service coverage area reflecting passenger attributes. Journal of the Eastern Asia Society for Transportation Studies, 6, 529-543. https://doi.org/10.11175/easts.6.529

Korneć, R. (2018). System transportu miejskiego wobec zrównoważonego rozwoju. Studia miejskie, 30, 71-84. https://doi.org/10.25167/sm2018.030.05

Liu, D., Xu, Z., Zhou, Y., \& Fan, C. (2019). Heat map visualisation of fire incidents based on transformed sigmoid risk model. Fire Safety Journal, 109, 102863. https://doi.org/10.1016/j.jlp.2021.104505

Lunke, E.B. (2020). Commuters' satisfaction with public transport. Journal of Transport \& Health, 16, 100842. https://doi.org/10.1016/j.jth.2020.100842

Majewska, A. (2021). Przekształcenia małych miast $w$ Polsce. Studium wybranych miast w strefie podmiejskiej Warszawy. Oficyna Wydawnicza Politechniki Warszawskiej.

Malasek, J. (2017). Metoda oceny dostępności i atrakcyjności przystanków miejskiego transportu zbiorowego. Transport Miejski i Regionalny, 9, 26-32.

Malczewski, J., \& Jaroszewicz, J. (2018). Podstawy analiz wielokryterialnych $w$ systemach informacji geograficznej. Oficyna Wydawnicza Politechniki Warszawskiej.

Miller, H., \& Wu, Y. (2000). GIS Software for Measuring Space-Time Accessibility in Transportation Planning and Analysis. Geolnformatica, 4(2), 141-159. https:// doi.org/10.1023/A:1009820006075

Ohannessian, R., Bénet, T., Argaud, L., Guérin, C., Guichon, C., Piriou, V., Rimmelé, T., Girard, R., Gerbier-Colomban, S., \& Vanhems, P. (2017). Heat map for data visualization in infection control epidemiology: An application describing the relationship between hospital-acquired infections, Simplified Acute Physiological Score II, and length of stay in adult intensive care units. American Journal of Infection Control, 45(7), 746-749. https://doi.org/ 10.1016/j.ajic.2017.02.012

Olszewski, R., Gotlib, D. \& Iwaniak, A. (2007). GIS. Obszary zastosowań. Wydawnictwo Naukowe PWN.

Pettit, C., Widjaja, I., Russo, P., Sinnott, R., Stimson, R., \& Tomko, M. (2012). Visualisation support for exploring urban space and place. ISPRS Annals of the Photogrammetry, Remote Sensing and Spatial Information Sciences, 1, 153-158. https:// doi.org/10.5194/isprsannals-I-2-153-2012

Pietrusiewicz, W. (1996). Problemy metodyczne opracowywania map dostępności czasowej. Polski Przegląd Kartograficzny, 28(2), 87-99.

Pokojski, W., Panecki, T., \& Słomska-Przech, K. (2021). Cartographic visualization of density: Exploring the opportunities and constraints of Heat Maps. Polish Cartographical Review, 53(1), 21-36. https:// doi.org/0.2478/pcr-2021-0003 
Polska w liczbach. (n.d.). Mińsk Mazowiecki (mazowieckie) w liczbach. Statistics Poland (GUS). Retrieved 24 August 2020, from https://www.polska wliczbach.pl/Minsk_Mazowiecki\#nieruchomosci

Rajaram, S. \& Oono,, Y. (2010). NeatMap--non-clustering heat map alternatives in R. BMC bioinformatics, 11(1), 45. https://doi.org/10.1186/1471 $-2105-11-45$

Roberts, D.J. (2020). Life in times of COVID-19. Transfusion Medicine, 30(3), 167-168. https://doi. org/10.1111/tme.12688

Sainio, J., Westerholm, J., \& Oksanen, J. (2015). Generating Heat Maps of Popular Routes Online from Massive Mobile Sports Tracking Application Data in Milliseconds While Respecting Privacy. ISPRS International Journal of Geo-information, 4(4), 1813-1826. https://doi.org/10.3390/ ijgi4041813

Sitek, K., Pokojski, W., \& Gołębiowska, I. (2020). Evaluation of time availability of the selected rescue service of a large city. A case study of Warsaw. Polish Cartographical Review, 52(4), 176-186. https://doi.org/10.2478/pcr-2020-0015
Słomska-Przech, K., Panecki, T. \& Pokojski, W. (2021). Heat Maps: Perfect Maps for Quick Reading? Comparing Usability of Heat Maps with Different Levels of Generalization. ISPRS International Journal of Geo-Information, 10(8), 562. https:// doi.org/10.3390/ijgi10080562

Suchecka, J. (Ed.). (2014). Statystyka przestrzenna. Metody analiz struktur przestrzennych. Wydawnictwo C.H. Beck.

Turk, I., Simunic, N., \& Zivic, D. (2016). Transport Accessibility As a Factor of Depopulation and Developmental Delay: Case Study Zumberak. Društvena Istraživanja, 25(2), 241-266. https:// doi.org/10.5559/di.25.2.05

Wang, B., Liu, Y., Qian, J., \& Parker, S.K. (2021). Achieving Effective Remote Working During the COVID-19 Pandemic: A Work Design Perspective. Applied psychology, 70(1), 16-59. https://doi. org/10.1111/apps.12290

Wilkinson, L., \& Friendly, M., (2009). The History of the Cluster Heat Map. The American Statistician, 63(2), 179-184. https://doi.org/10.1198/tas.2009.0033 